\title{
Potential Estrogenic and Antiandrogenic Effects of Permethrin in Rats
}

\author{
Soon-Sun KIM ${ }^{1)}$, Rhee-Da LEE ${ }^{1)}$, Kwon-Jo LIM ${ }^{1)}$, Seung-Jun KWACK ${ }^{1)}$, \\ Gyu-Seek RHEE ${ }^{1)}$, Ji-Hyun SEOK ${ }^{1}$, Geun-Shik LEE ${ }^{2)}$, Beum-Soo AN ${ }^{2)}$, \\ Eui-Bae JEUNG ${ }^{2)}$ and Kui-Lea PARK')
}

\author{
1) National Institute of Toxicological Research, Korea Food and Drug Administration, Seoul \\ 122-704, and ${ }^{2}$ Laboratory of Veterinary Biochemistry and Molecular Biology, College of \\ Veterinary Medicine, Chungbuk National University, Cheongju 361-763, Korea
}

\begin{abstract}
Many environmental chemicals including pesticides have been reported to possess hormonal activities, and thus are classified as endocrine disruptors. Permethrin, a synthetic pyrethroid insecticide, is used worldwide, which provides potential environmental exposure. However, relatively few studies have reported on hormonal activities, particularly estrogenic and androgenic activities of permethrin, and the results of these studies are in some respects contradictory. Therefore, this study investigated the potential estrogenic and androgenic activities of permethrin in vitro and in vivo. We conducted an uterine Calbindin- $\mathrm{D}_{9 \mathrm{k}}(\mathrm{CaBP}-9 \mathrm{k})$ gene expression assay and an uterotrophic assay for estrogenic activity, and a Hershberger assay for androgenic activity. The CaBP$9 \mathrm{k}$ gene, one of the intracellular calcium binding proteins, is estrogen-responsive in the uterus. The rat uterotrophic and Hershberger assays are generally used as in vivo short-term screening assays for detecting the estrogenic and androgenic activities of chemicals, although these assays are still being validated by the Organization for Economic Cooperation and Development (OECD). Northern blot analysis showed the induction of uterine CaBP-9k mRNA level in response to permethrin as well as co-administration of permethrin with E2. In the uterotrophic assay using 18-day-old female rats, subcutaneous treatments with permethrin $(10$ to $800 \mathrm{mg} / \mathrm{kg})$ for three days increased relative uterine wet weights, and E2-induced uterine weights. These effects were statistically significant at 800 and $200 \mathrm{mg} / \mathrm{kg}$, respectively. Moreover, permethrin-induced uterine weights were inhibited by the coadministration of ICI 182,780, an antiestrogen. In the Hershberger assay, the administration of permethrin orally to testosterone propionate-treated castrated male rats led to statistically significant reductions in androgen-dependent sex accessory tissue (ventral prostate, seminal vesicles, levator ani and bulbocavernosus muscles, Cowper's gland and glans penis) weights at all doses tested (10,50 and $100 \mathrm{mg} / \mathrm{kg}$ ). These results suggest that permethrin might have estrogen-like effects on female rats, but antiandrogen-like effects on males.
\end{abstract}

Key words: Permethrin, Estrogenic activity, Antiandrogenic activity, Immature rat, Uterotrophic assay, Calbindin- $\mathrm{D}_{9 \mathrm{k}}$ gene expression assay, Hershberger assay

(J. Reprod. Dev. 51: 201-210, 2005)

ncreasing concern is being expressed that many environmental chemicals have hormonal activity, and thus could affect the endocrine

Accepted for publication: November 9, 2004

Published online: December 15, 2004

Correspondence: S-S, KIM (e-mail : sskeem@kfda.go.kr) systems and developmental outcomes of wildlife and humans [1-4]. Pyrethroid insecticides, synthetic derivatives of pyrethrins, are known to exert their insecticidal actions by altering the sodium permeabilities of insect nerve membranes by modulating voltage-sensitive sodium channels 
[5-7]. Of these insecticides, permethrin (3-(2,2dichloroethenyl)-2,2-dimethylcyclopropanecarboxylic acid (3-phenoxyphenyl) methyl ester) is being increasingly used to protect domestic animals and the public, as well as agriculture from a variety of pests such as flies, fleas, mosquitoes, headlice, and mites, in both developed and developing countries [8-14]. Moreover, permethrin is registered as being suitable for application to clothing as an insect repellent to prevent West Nile virus in USA. These situations provide the potential for environmental exposure to permethrin and its attendant human health risks. Many pesticides have been reported to possess estrogenic or androgenic activities [15-22], and thus are classified as endocrine disruptors. However, relatively few studies have reported on the estrogenic and androgenic activities of permethrin [3, 23-26], and the results of the studies are in some respects contradictory. Accordingly, more investigation is needed to clarify the estrogenic and androgenic activities of permethrin. The calbindin- $\mathrm{D}_{9 \mathrm{k}}(\mathrm{CaBP}-9 \mathrm{k})$ gene is an intracellular calcium binding protein, which is present in a variety of cells, but which is mainly expressed in the intestine, lung and uterus. The CaBP-9k gene is dependent on vitamin-D in the intestine, whereas it is estrogen-responsive in the uterus [27-30]. In non-pregnant rats, the CaBP-9k gene is present in the myometrium and in stromal cells of the uterus, but is not expressed in the immature rat uterus. Although this gene contains an imperfect estrogen responsive element (ERE) that differs by only one nucleotide from the vitallogenin consensus, it binds to the estrogen receptor [30]. The Organization for Economic Cooperation and Development (OECD) proposed a rodent uterotrophic assay and a Hershberger assay as in vivo short-term screening assays for detecting the estrogenic and androgenic properties of suspected endocrine disrupting chemicals in 2001, and both of these assays continue to be validated by the OECD. In the uterotrophic assay, the test protocols involve an immature rat uterotrophic assay, whereby chemicals are subcutaneously administered to immature female rats for three consecutive days. The Hershberger assay has been commonly used to determine the androgenic and antiandrogenic activities of certain chemicals [19, 20, 25, 31, 32]. In this study, we examined the potential estrogenic activity of permethrin by immature rat uterotrophic assay, and the uterine CaBP-9k gene expression assay. Further, the Hershberger assay was used to determine the androgenic activity of permethrin.

\section{Materials and Methods}

\section{Chemicals}

Permethrin (CAS no:52645-53-1, 96.6\% pure, mixture of cis $(24.8 \%)$ and trans $(71.8 \%)$ isomers) was obtained from Riedel-dehaën (Wunstorferasse, Germany). Details of the other chemicals used in this study and their purities are as follows. Corn oil, (Sigma, St. Louis, MO, USA); $17 \beta$-Estradiol (E2), CAS no. 50-28-2, 98.0\% pure, (Sigma); ICI 182, 780, $>99 \%$ pure, (TOCRIS, Bristol, UK); testosterone propionate (TP), CAS no. 57-85-2, $\geq 97.0 \%$ pure (Wako, Osaka, Japan); flutamide, CAS no. 3331184-7 (Sigma, USA); and 4,4'-dichlorodiphenyldichloroethylene ( $\mathrm{p}, \mathrm{p}^{\prime}$-DDE), CAS no. 72-55-9, 99.9\% pure (Sigma). Of these chemicals, E2 was used as an estrogen, and ICI 182, 780 as an antiestrogen in the uterotrophic assay, and TP and flutamide or $\mathrm{p}, \mathrm{p}^{\prime}$-DDE were used as a reference androgen and antiandrogens, respectively.

\section{Animals}

In this study, we used Sprague-Dawley rats bred at our institute (National Institute of Toxicological Research, Korea Food and Drug Administration, Seoul, Korea. All animals used in this experiment were handled in an accredited Korean animal facility in accordance with the AAALAC International Animal Care policy (Accredited Unit, Korea Food and Drug Administration; Unit Number-000996). Animals were housed in polycarbonate cages under a strict light cycle (light on at 06:00 hours and off at 18:00 hours). In addition, all animals were given irradiated rodent chow diet (Biophia Inc., Gunpo, Korea) ad libitum, and were housed at $23 \pm 2 \mathrm{C} / \mathrm{RH} 55 \pm 5 \%$.

\section{Northern blot analysis of CaBP-9k mRNA}

For the Northern blot analysis of CaBP-9k mRNA, uterine tissues obtained from uterotrophic assays were snap-frozen in liquid nitrogen. Three frozen uteri per group were individually homogenized, and total RNA was extracted using Trizol reagent (Life Technologies, Rockvill, MD, USA). RNAs were denatured by heating at $65 \mathrm{C}$ for 
$15 \mathrm{~min}$, and $10 \mathrm{mg}$ of total RNA were electrophoresed in $1 \%$ agarose gel for $90 \mathrm{~min}$ at 110 $\mathrm{V}$, and then transferred to a nylon membrane using a vacuum blotter. $18 \mathrm{~S}$ rRNA was used as an indicator of total RNA quality.

\section{Uterotrophic assay}

The estrogenic activities of permethrin in vivo were examined by immature rat uterotrophic assays using $17 \beta$-estradiol (E2) as a positive control. Immature Sprague -Dawley female rats (18-daysold) were randomly assigned to the control and treatment groups. Permethrin (10 to $800 \mathrm{mg} / \mathrm{kg})$, or permethrin (10 to $800 \mathrm{mg} / \mathrm{kg}$ ) plus E2 $(3 \mu \mathrm{g} / \mathrm{kg})$, or ICI $182,780(3 \mu \mathrm{g} / \mathrm{kg})$ were administered to 19 to 21-day-old rats by subcutaneous injection. All chemicals were dissolved in $5 \mathrm{ml}$ of corn oil before treatment. Animals were sacrificed by cervical dislocation $24 \mathrm{~h}$ after the final treatment. The uteri and vaginae were removed, trimmed free of fat, and weighed.

\section{Hershberger assay}

The Hershberger assay was performed according to the current draft guidelines of the rodent Hershberger assay (OECD, 2002). Sprague-Dawley male rats were castrated (removal of testis and epididymis via incision of the middle scrotum under ether anesthesia at 5 weeks old). To examine the androgenic activity of permethrin, it was administered daily $(10,50$ or $100 \mathrm{mg} / \mathrm{kg} /$ day $)$ to castrated rats by oral gavage for 10 days. As a reference androgen, $0.4 \mathrm{mg} / \mathrm{kg}$ of TP was injected once into the dorsal surface of castrated rats. To examine the antiandrogenic activity of permethrin, it was administered $(10,50$ or $100 \mathrm{mg} / \mathrm{kg} /$ day $)$ to TP-treated castrated rats by oral gavage for 10 days. Flutamide (25 mg/kg/day) and p,p'-DDE (100 $\mathrm{mg} / \mathrm{kg} / \mathrm{day}$ ) were used as reference antiandrogens. Animals were evaluated at least once daily for mortality, signs of injury and general appearance. Individual body weights and food consumption were determined at treatment start, and recorded once every three days until the last treatment during the administration period. Twenty-four hours after the final administration, five sex accessory tissues (ventral prostate; VP; seminal vesicle, SV; levator ani plus bulbocavernosus muscles, LABC; Cowper's gland, COW; and glans penis, GP) were excised, carefully trimmed of excess adhering tissue and fat, and weighed.

\section{Statistical analysis}

Experimental results are presented as means \pm SEM. Experimental data were analyzed by one way analysis of variance (ANOVA), and multiple comparisons versus the control group were performed by Dunnett's Method using SigmaStat 2.03. In the uterotrophic assay, permethrin plus ICI 182,780 -treated groups were compared to corresponding permethrin-treated groups. Significant differences between the groups were evaluated at $p$ levels of 0.01 and 0.05 .

\section{Results}

\section{CaBP-9k $m R N A$ expression}

Northern blot analysis showed that CaBP-9k mRNA was up-regulated by permethrin, and that permethrin enhanced the E2-induced CaBP-9k mRNA level (Fig. 1). A permethrin dose of $5 \mathrm{mg} /$ $\mathrm{kg}$, the lowest dose, maximally induced CaBP-9k mRNA expression in response to permethrin, and co-administration of permethrin with E2.

\section{Uterotrophic assay}

E2 $(0.3,3$ and $10 \mu \mathrm{g} / \mathrm{kg})$, used as a positive control, significantly increased uterine and vaginal wet weights, and showed maximal increases at 3 $\mu \mathrm{g} / \mathrm{kg}$ (data not shown). Therefore, $3 \mu \mathrm{g} / \mathrm{kg}$ was set as the E2 dose in this assay. Uterine and vaginal weights are presented as relative wet weights. E2 ( $3 \mu \mathrm{g} / \mathrm{kg}$ ) caused about 3.8 and 2.4 fold increases in relative uterine and vaginal wet weights versus the

A

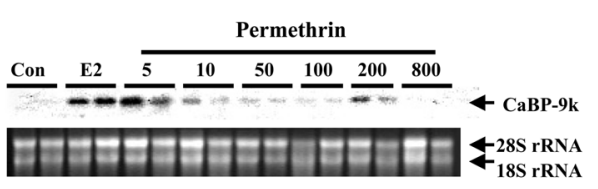

B

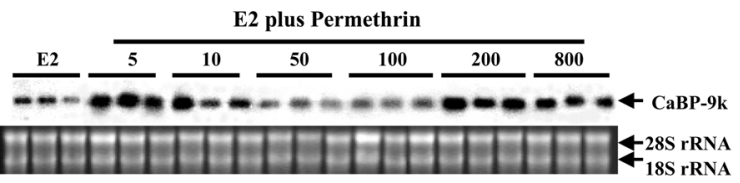

Fig. 1. Expression of uterine CaBP-9k mRNA in immature female rats treated with permethrin (5 to $800 \mathrm{mg} / \mathrm{kg}$ ) (A) or E2 $(3 \mu \mathrm{g} / \mathrm{kg}$ ) plus permethrin (5 to $800 \mathrm{mg} / \mathrm{kg}$ ) (B). 

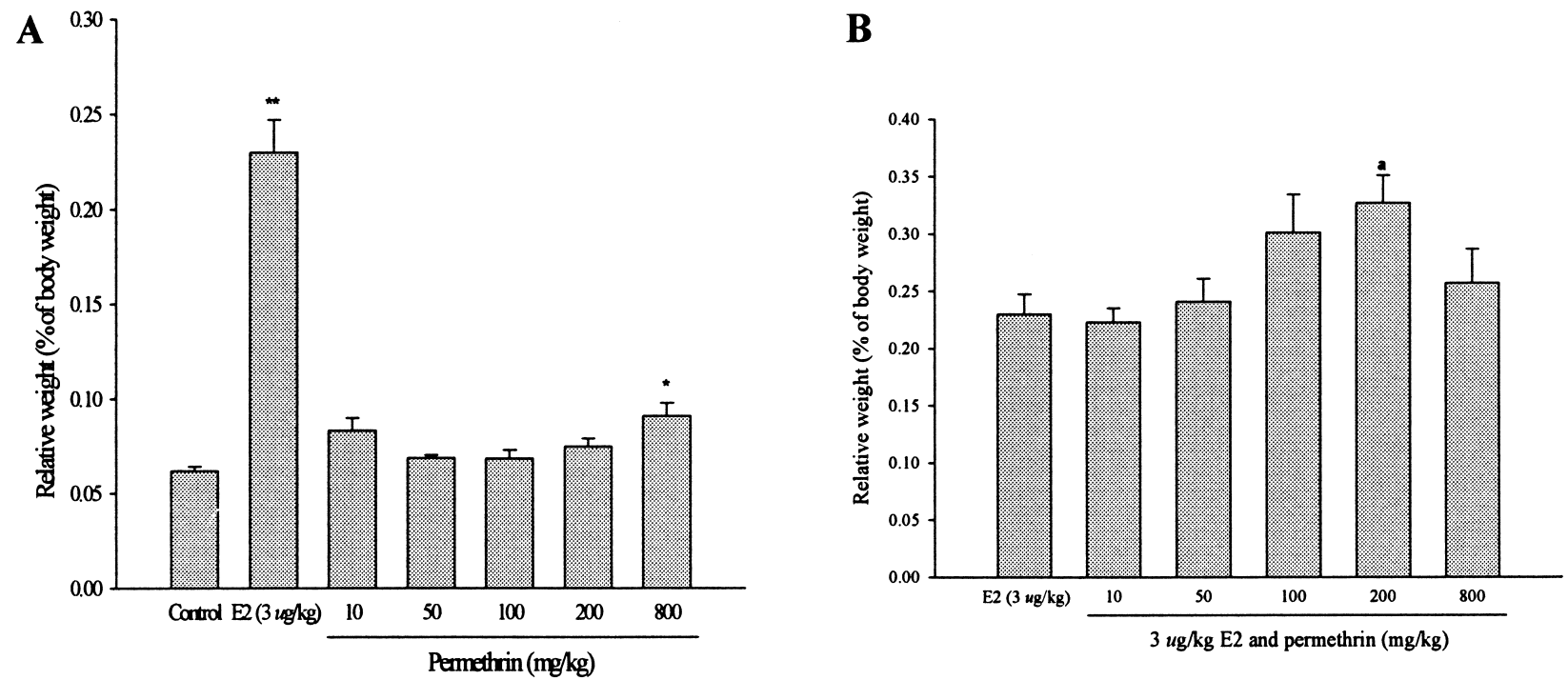

Fig. 2. Relative uterine wet weights in immature female rats treated with permethrin (A) or E2 plus permethrin (B). Data are presented as means \pm SEM $(\mathrm{N}=8-12)$. ${ }^{*}$ Significantly different from the control, $\mathrm{P}<0.05$, ${ }^{* *}$ Significantly different from the

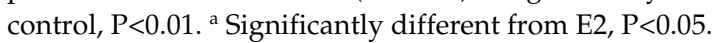

Table 1. Effects of ICI 182,780 on uterine wet weights in permethrin-treated female rats

\begin{tabular}{|c|c|c|c|}
\hline \multicolumn{2}{|c|}{ Treatment (dose: $\mathrm{mg} / \mathrm{kg}$ ) } & \multirow{2}{*}{$\begin{array}{c}\text { Body weight } \\
(\mathrm{g})\end{array}$} & \multirow{3}{*}{$\begin{array}{c}\begin{array}{c}\text { Uterine weight } \\
\text { (\% of body weight) }\end{array} \\
0.111 \pm 0.010 \\
0.101 \pm 0.006\end{array}$} \\
\hline Permethrin (10) & & & \\
\hline Permethrin (10) & $+\mathrm{ICI}(0.003)$ & $45.07 \pm 0.88$ & \\
\hline Permethrin (50) & & $45.01 \pm 1.57$ & $0.110 \pm 0.010$ \\
\hline Permethrin (50) & $+\mathrm{ICI}(0.003)$ & $39.02 \pm 2.90$ & $0.066 \pm 0.003^{*}$ \\
\hline Permethrin (100) & & $45.33 \pm 0.54$ & $0.075 \pm 0.002$ \\
\hline Permethrin (100) & $+\operatorname{ICI}(0.003)$ & $42.28 \pm 3.68$ & $0.086 \pm 0.007$ \\
\hline Permethrin (200) & & $42.86 \pm 1.56$ & $0.089 \pm 0.011$ \\
\hline Permethrin (200) & $+\mathrm{ICI}(0.003)$ & $36.78 \pm 3.23$ & $0.079 \pm 0.004$ \\
\hline Permethrin (800) & & $45.31 \pm 1.14$ & $0.068 \pm 0.003$ \\
\hline Permethrin (800) & $+\mathrm{ICI}(0.003)$ & $38.79 \pm 4.41$ & $0.059 \pm 0.005$ \\
\hline
\end{tabular}

Data are presented as means \pm SEM $(\mathrm{N}=8-12) .{ }^{*}$ Significantly different from permethrin (50), $\mathrm{P}<0.01$.

control, respectively. Subcutaneous treatment of permethrin (10 to $800 \mathrm{mg} / \mathrm{kg}$ ) increased uterine wet weights, and enhanced E2-induced uterine wet weights at all doses tested (Fig. 2). These effects were statistically significant, and showed maximal increases at permethrin doses of 800 and $200 \mathrm{mg}$ / $\mathrm{kg}$ respectively. To confirm the maximal increase in uterine weight by permethrin observed in this assay, permethrin was administered to immature female rats at up to $1,200 \mathrm{mg} / \mathrm{kg}$, but no further increases in uterine weights were observed (data not shown). Increases in uterine weights by permethrin were inhibited by co-treatment with ICI 182,780 , an antiestrogen (Table 1), confirming the estrogenic activity of permethrin. In addition, permethrin showed a tendency to increase vaginal wet weights, although this was not statistically significant (Table 2).

\section{Hershberger assay}

Table 3 presents the androgen-dependent tissue weights obtained by Hershberger assay for the 
Table 2. Body and vaginal wet weights in immature female rats treated with permethrin

\begin{tabular}{lcc}
\hline Treatment (dose: $\mathrm{mg} / \mathrm{kg} /$ day) & Body weight $(\mathrm{g})$ & $\begin{array}{c}\text { Relative vaginal weight } \\
\text { (\% of body weight) }\end{array}$ \\
\hline Control & $58.97 \pm 1.60$ & $0.051 \pm 0.005$ \\
17 $\beta$ - estradiol (E2; 0.003) & $60.20 \pm 1.93$ & $0.121 \pm 0.008^{*}$ \\
Permethrin (10) & $59.08 \pm 3.21$ & $0.058 \pm 0.003$ \\
$\quad(50)$ & $60.62 \pm 3.86$ & $0.057 \pm 0.003$ \\
$(100)$ & $61.68 \pm 3.65$ & $0.060 \pm 0.008$ \\
$\quad(200)$ & $66.69 \pm 3.00$ & $0.056 \pm 0.004$ \\
$\quad(800)$ & $59.97 \pm 3.35$ & $0.051 \pm 0.004$ \\
E2 + Permethrin (10) & $60.73 \pm 6.06$ & $0.128 \pm 0.013$ \\
E2 + Permethrin (50) & $59.41 \pm 2.65$ & $0.132 \pm 0.019$ \\
E2 + Permethrin (100) & $61.73 \pm 2.88$ & $0.133 \pm 0.013$ \\
E2 + Permethrin (200) & $64.68 \pm 2.21$ & $0.117 \pm 0.009$ \\
E2 + Permethrin (800) & $70.48 \pm 1.58$ & $0.106 \pm 0.017$ \\
\hline
\end{tabular}

Data are presented as means \pm SEM $(\mathrm{N}=8-12)$. Significantly different from control, $\mathrm{P}<0.01$.

Table 3. Androgen-dependent sex accessory tissue weights in the Hershberger assay for androgen agonist

\begin{tabular}{|c|c|c|c|c|c|c|c|c|c|c|}
\hline \multirow[b]{2}{*}{ Treatment } & \multirow{2}{*}{\multicolumn{2}{|c|}{$\begin{array}{c}\text { Dose } \\
(\mathrm{mg} / \mathrm{kg} / \text { day })\end{array}$}} & \multirow[b]{2}{*}{ Body weight } & \multicolumn{4}{|c|}{ Ventral prostate } & \multicolumn{3}{|c|}{ Seminal vesicle } \\
\hline & & & & \multicolumn{2}{|c|}{$\begin{array}{l}\text { Absolute weight } \\
(\mathrm{g})\end{array}$} & \multicolumn{2}{|c|}{$\begin{array}{l}\text { Relativeweight } \\
\text { (\% of body weight) }\end{array}$} & \multicolumn{2}{|c|}{$\begin{array}{l}\text { Absolute weight } \\
\text { (g) }\end{array}$} & $\begin{array}{l}\text { Relativeweight } \\
\% \text { of body weight) }\end{array}$ \\
\hline \multicolumn{3}{|l|}{ Control } & $321.91 \pm 3.85$ & \multicolumn{2}{|c|}{$0.0174 \pm 0.0011$} & \multicolumn{2}{|c|}{$0.0054+0.0003$} & \multicolumn{2}{|c|}{$0.0593 \pm 0.0291$} & $0.0185 \pm 0.0010$ \\
\hline $\begin{array}{l}\text { Testosterone } \\
\text { propionate }\end{array}$ & \multicolumn{2}{|l|}{0.4} & $345.10 \pm 6.60$ & \multicolumn{2}{|c|}{$0.1863 \pm 0.0146^{*}$} & \multicolumn{2}{|c|}{$0.0540 \pm 0.0040^{*}$} & \multicolumn{2}{|c|}{$0.7085 \pm 0.0520^{*}$} & $0.2056 \pm 0.0149^{*}$ \\
\hline Permethrin & \multicolumn{2}{|l|}{$\begin{array}{c}10 \\
50 \\
100\end{array}$} & $\begin{array}{l}320.30 \pm 7.62 \\
313.38 \pm 9.91 \\
328.22 \pm 6.68\end{array}$ & \multicolumn{2}{|c|}{$\begin{array}{l}0.0190 \pm 0.0008 \\
0.0157 \pm 0.0019 \\
0.0201 \pm 0.0016\end{array}$} & \multicolumn{2}{|c|}{$\begin{array}{l}0.0059 \pm 0.0002 \\
0.0050 \pm 0.0006 \\
0.0061 \pm 0.0004\end{array}$} & \multicolumn{2}{|c|}{$\begin{array}{l}0.0636 \pm 0.0066 \\
0.0668 \pm 0.0056 \\
0.0727 \pm 0.0050\end{array}$} & $\begin{array}{l}0.0198 \pm 0.0020 \\
0.0214 \pm 0.0018 \\
0.0221 \pm 0.0014\end{array}$ \\
\hline \multirow[b]{2}{*}{ Treatment $(\mathrm{m}$} & \multirow{2}{*}{$\begin{array}{c}\text { Dose } \\
\text { (mg/kg/day) }\end{array}$} & \multicolumn{3}{|c|}{ LABC } & \multicolumn{3}{|c|}{ Glans penis } & \multicolumn{3}{|c|}{ Cowper's gland } \\
\hline & & Abso & $\begin{array}{l}\text { lute weight } \\
\text { (g) }\end{array}$ & $\begin{array}{c}\text { Relativeweight } \\
\text { (\% of body weight) }\end{array}$ & Abs & $\begin{array}{l}\text { oluteweight } \\
\text { (g) }\end{array}$ & $\begin{array}{r}\text { Relative } \\
(\% \text { of body }\end{array}$ & $\begin{array}{l}\text { eight } \\
\text { veight) }\end{array}$ & $\begin{array}{l}\text { Absoluteweight } \\
\text { (g) }\end{array}$ & $\begin{array}{l}\text { Relativeweight } \\
\text { (\% of body weight) }\end{array}$ \\
\hline Control & & 0.269 & $98 \pm 0.0081$ & $0.0836 \pm 0.0024$ & 0.05 & $532 \pm 0.0017$ & 0.0165 & 0.0005 & $0.0105 \pm 0.0006$ & $0.0032 \pm 0.0002$ \\
\hline $\begin{array}{l}\text { Testosterone } \\
\text { propionate }\end{array}$ & 0.4 & 0.667 & $71 \pm 0.0296^{*}$ & $0.1937 \pm 0.0096^{*}$ & 0.08 & $353 \pm 0.0051^{*}$ & 0.0248 & $0.0016^{*}$ & $0.0489 \pm 0.0048^{*}$ & $8^{*} \quad 0.0142 \pm 0.0014^{*}$ \\
\hline Permethrin & $\begin{array}{c}10 \\
50 \\
100\end{array}$ & $\begin{array}{l}0.267 \\
0.277 \\
0.281\end{array}$ & $\begin{array}{l}78 \pm 0.0132 \\
71 \pm 0.0096 \\
15 \pm 0.0168\end{array}$ & $\begin{array}{l}0.0836 \pm 0.0035 \\
0.0884 \pm 0.0010 \\
0.0859 \pm 0.0051\end{array}$ & $\begin{array}{l}0.05 \\
0.04 \\
0.05\end{array}$ & $\begin{array}{l}525 \pm 0.0019 \\
486 \pm 0.0018 \\
507 \pm 0.0012\end{array}$ & $\begin{array}{l}0.0165 \\
0.0156 \\
0.0155\end{array}$ & $\begin{array}{l}0.0007 \\
0.0006 \\
0.0004\end{array}$ & $\begin{array}{l}0.0097 \pm 0.0010 \\
0.0110 \pm 0.0012 \\
0.0124 \pm 0.0014\end{array}$ & $\begin{array}{l}0.0030 \pm 0.0003 \\
0.0035 \pm 0.0003 \\
0.0038 \pm 0.0004\end{array}$ \\
\hline
\end{tabular}

Data are presented as means \pm SEM $(\mathrm{N}=6-8) .{ }^{*}$ Significantly different from the control, $\mathrm{P}<0.01$.

androgenic activity of permethrin. The results show that testosterone propionate (TP), a reference androgen induced significant increases in the absolute and relative weights of androgendependent sex accessory tissues (VP, SV, LABC, COW, and GP). In order of increasing potency these were ranked as SV (12) > VP (11) > COW (4.5) $>$ LABC (2.5) > GP (1.5); the numbers in parentheses refer to fold increases compared to the control. These results indicate that of the androgen-dependent tissues tested, the seminal vesicle was most sensitive to androgen. On the other hand, permethrin did not affect the androgen-dependent tissue weights at any dose tested, suggesting that it has no androgenic activity. In addition, TP showed no clinical signs, but did produce a statistically significant increase in food consumption, and an enhancement of body weight. Similarly, statistically significant increases in food consumption were observed in the permethrin-treated groups during the administration period (Table 4). 
Table 4. Body weights and food consumptions in the Hershberger assay for androgen agonist

\begin{tabular}{lcccc}
\hline \multirow{2}{*}{ Treatment } & \multirow{2}{*}{$\begin{array}{c}\text { Dose } \\
\text { (mg/kg/day) }\end{array}$} & \multicolumn{2}{c}{ Body weight } & Food consumption \\
\cline { 3 - 5 } & & Initial weight $(\mathrm{g})$ & Final weight $(\mathrm{g})$ & (g/rat/day) \\
\hline Control & & $267.50 \pm 2.80$ & $321.91 \pm 3.85$ & $19.26 \pm 0.27$ \\
\hline Testosterone propionate & 0.4 & $266.60 \pm 4.66$ & $345.10 \pm 6.60$ & $25.07 \pm 0.15^{* *}$ \\
\hline \multirow{3}{*}{ Permethrin } & 10 & $273.51 \pm 6.41$ & $320.30 \pm 7.62$ & $19.21 \pm 0.30$ \\
& 50 & $265.66 \pm 6.72$ & $313.38 \pm 9.91$ & $19.32 \pm 0.29$ \\
& 100 & $273.15 \pm 5.79$ & $328.22 \pm 6.68$ & $20.47 \pm 0.35^{*}$ \\
\hline
\end{tabular}

Data are presented as means \pm SEM $(\mathrm{N}=6-8) .{ }^{*}$ Significantly different from control, $\mathrm{P}<0.05,{ }^{* *}$ Significantly different from control, $\mathrm{P}<0.01$

Table 5. Body weights and food consumptions in the Hershberger assay for androgen antagonist

\begin{tabular}{lcccc}
\hline \multirow{2}{*}{ Treatment } & $\begin{array}{c}\text { Dose } \\
(\mathrm{mg} / \mathrm{kg} / \text { day })\end{array}$ & \multicolumn{2}{c}{ Body weight } & Food consumption \\
\cline { 3 - 5 } & & Initial weight $(\mathrm{g})$ & Final weight $(\mathrm{g})$ & (g/rat/day) \\
\hline Testosterone propionate & 0.4 & $265.85 \pm 4.16$ & $338.41 \pm 14.24$ & $25.42 \pm 0.32$ \\
\hline p,p'-DDE & 100 & $264.81 \pm 2.24$ & $343.99 \pm 4.55$ & $18.11 \pm 0.89^{*}$ \\
\hline Flutamide & 25 & $273.29 \pm 3.58$ & $330.78 \pm 5.45$ & $21.44 \pm 0.02^{*}$ \\
\hline \multirow{3}{*}{ Permethrin } & 10 & $271.99 \pm 4.41$ & $343.40 \pm 5.21$ & $21.60 \pm 0.17^{*}$ \\
& 50 & $271.13 \pm 2.75$ & $345.71 \pm 3.97$ & $22.07 \pm 0.06^{*}$ \\
\hline
\end{tabular}

Data are presented as means \pm SEM $(\mathrm{N}=6-8) .{ }^{*}$ Significantly different from testosterone propionate, $\mathrm{P}<0.01$.

Flutamide $(25 \mathrm{mg} / \mathrm{kg})$ and $\mathrm{p}, \mathrm{p}^{\prime}$-DDE $(100 \mathrm{mg} /$ $\mathrm{kg})$, reference antiandrogens significantly reduced TP $(0.4 \mathrm{mg} / \mathrm{kg})$-induced food consumption by 28.76 and $15.66 \%$, respectively. Likewise, TPtreated castrated male rats showed statistically significant reductions in food consumption by permethrin treatment at all doses tested (Table 5). Flutamide $(25 \mathrm{mg} / \mathrm{kg})$ and $\mathrm{p}, \mathrm{p}^{\prime}$-DDE $(100 \mathrm{mg} / \mathrm{kg})$ remarkably reduced sex accessory tissue weights (VP, SV, LABC, COW and GP) versus the TP (0.4 $\mathrm{mg} / \mathrm{kg}$ )-treated group. In terms of reducing potency, this was ranked as: SV (20) > VP (16) > COW (7) > LABC (1.8) > GP (1.3) by flutamide, and SV and VP (both, 2.7) > COW (1.9) > LABC (1.8) > GP (1.3) by $p, p^{\prime}$-DDE; the numbers in parentheses refer to fold reductions compared to the TP-treated group. These results are in agreement with the Hershberger assay for androgenic activity. Thus, it seems that the seminal vesicle is the tissue most dependent on both androgen and antiandrogen. Likewise, the administration of permethrin to TPtreated castrated rats led to statistically significant reductions in the five sex accessory tissue weights at all doses tested (Figs. 3 and 4), suggesting that permethrin has antiandrogenic activity.

\section{Discussion}

We examined the estrogenic activity of permethrin by an immature rat uterotrophic assay and an uterine CaBP-9k mRNA expression assay. The androgenic activity of permethrin was also determined by the Hershberger assay. In the present study, permethrin was found to have estrogen-like effects on female rats, but antiandrogen-like effects on males. Our results are partially consistent with previous results of permethrin, but also differ in some respects. Our uterine CaBP-9k mRNA expression assay performed by Northern blot analysis showed the induction of uterine CaBP-9k mRNA expression in response to permethrin, and co-administration of permethrin with E2. Although several in vitro studies have been reported on the estrogenic or antiestrogenic potential of permethrin, results are inconsistent. Garey and Wolff reported that permethrin showed no statistically significant estrogen- antagonist activity in the Ishigawa Var-1 human endometrial cancer cell line or in the T47D human breast cancer cell line at $100 \mu \mathrm{M}$ [23]. However, Go et al. showed that permethrin (100 

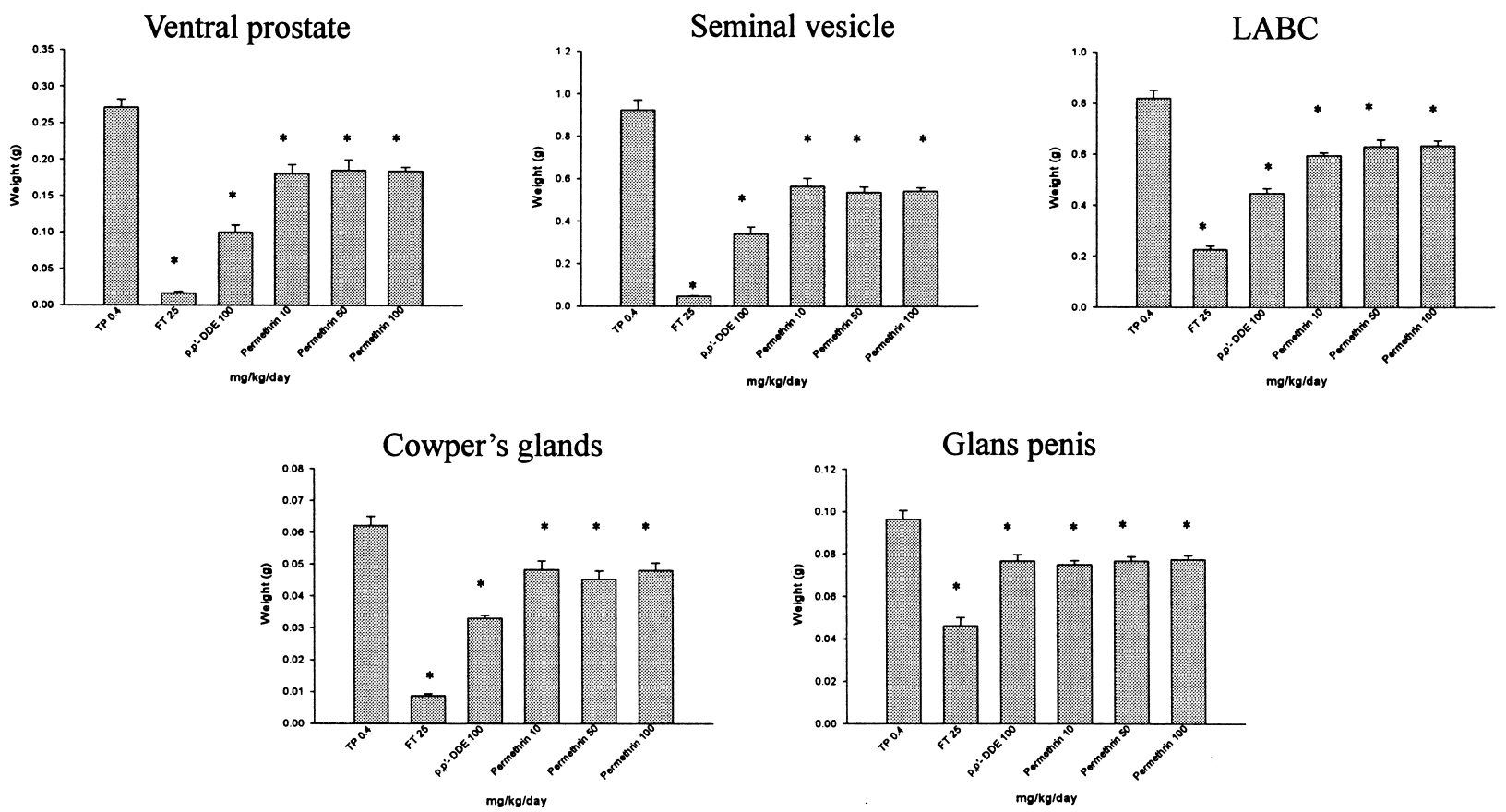

Fig. 3. Effects of permethrin on absolute sex accessory tissue weights in the Hershberger assay for androgen antagonist. Castrated SD male rats subcutaneously injected with testosterone propionate (TP) were treated with permethrin by oral gavage for 10 days (p,p'-DDE, 4,4'-dichlorodiphenyl dichloroethylene: FT, flutamide: LABC, levator ani and bulbocavernosus muscles). Data are presented as means \pm SEM. ${ }^{*}$ Significantly different from $\mathrm{TP}, \mathrm{P}<0.01$.

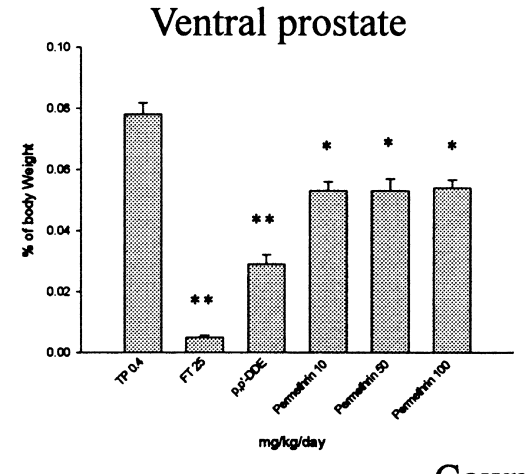

Cowper's glands

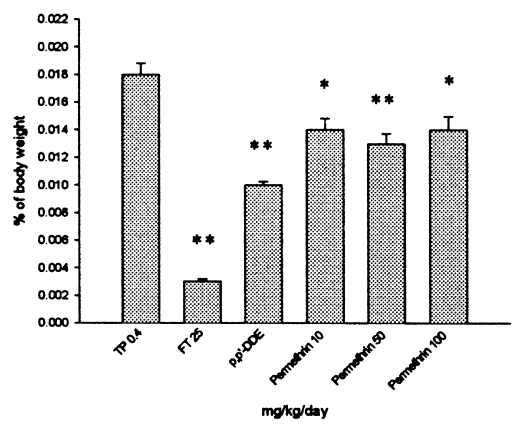

Seminal vesicle

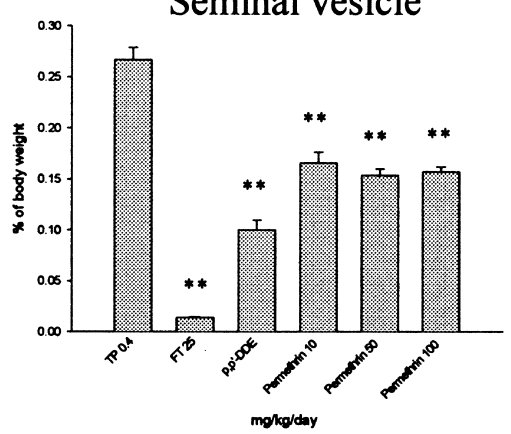

LABC

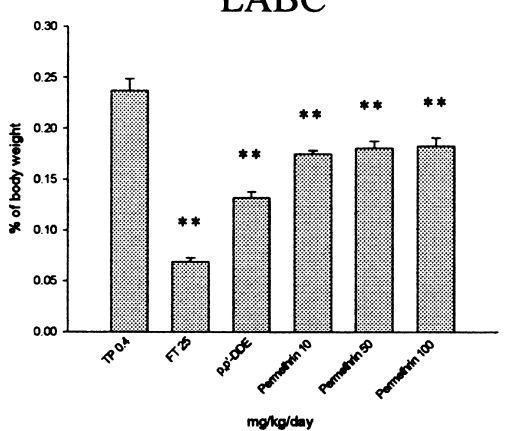

Glans penis

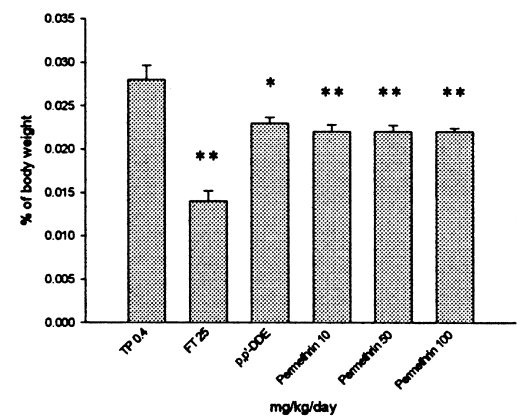

Fig. 4. Effects of permethrin in relative sex accessory tissue weights in Hershberger assay for androgen antagonist. Castrated SD male rats subcutaneously injected with testosterone propionate (TP) were treated with permethrin by oral gavage for 10 days (p,p'-DDE, 4,4'-dichlorodiphenyl dichloroethylene: FT, flutamide: LABC, levator ani and bulbocavernosus muscles). Data are presented as means \pm SEM. * Significantly different from the control, $\mathrm{P}<0.05,{ }^{* *}$ Significantly different from TP, $\mathrm{P}<0.01$. 
$\mu \mathrm{M})$ noticeably induced the proliferation of MCF-7 human breast cancer cells [33]. Saito et al. reported the lack of an estrogenic effect for permethrin in a luciferase reporter gene assay using HeLa cells and a yeast two-hybrid assay [24], whereas Tyler et al. found that permethrin showed estrogenic activity and an additive estrogenic response in a human estrogen receptor yeast screen assay [3]. Chen et al. reported that permethrin produces an ER-specific agonist response based on the induction of MCF-7 cell proliferation and pS2 mRNA expression in MCF-7 cells, and inhibition of binding $\left[{ }^{3} \mathrm{H}\right]$ estradiol to ER [26]. Gierthy et al. proposed MCF-7 cell foci formation as an endpoint for the detection of the estrogenic actions of environmental chemicals [34]. Zou et al. tested this possibility using an in vitro screening method to identify estrogenic compounds acting through a c-Neu mediated mechanism using some environmental chemicals such as Aroclor 1242, PCB 95, and cisand trans- permethrins [37]. They reported that the cis- and trans-isomers of permethrin showed a significant promoting effect on MCF-7 cell foci formation, and suggested that the estrogenic activity of permethrin might be mediated via the cNeu pathway. These results are in agreement with our findings in terms of the estrogenic activity of permethrin, but the action mechanism suggested by Zou et al. [37] differs from that suggested by our data, which indicates the involvement of an ERmediated pathway. In the present study, the uterotrophic assay showed that permethrin (10 to $800 \mathrm{mg} / \mathrm{kg}$ ) increased uterine wet weights. But the uterine weights increased by permethrin were reduced by co-treatment with ICI 182,780 , an antiestrogen, thus indicating the estrogenic activity of permethrin. Kunimatsu et al. assessed the estrogenic activity of permethrin using an uterotrophic assay, and reported the lack of an estrogenic effect for permethrin based on the absence of no increases in the weights of uteri [25]. In this uterotrophic assay, 8-week-old ovariectomized Sprague-Dawley rats were used, and permethrin $(37.5,75$ or $150 \mathrm{mg} / \mathrm{kg} /$ day) was administered by oral gavage for 3 days. The inconsistency between Kunimatsu's data and ours in terms of uterotrophic response appears to be due to differences in the animal models and treatment routes used. In the Hershberger assay for androgenic activity, testosterone propionate, a reference androgen induced significant increases in the absolute and relative weights of androgendependent tissues, and this increasing potency was ranked as $\mathrm{SV}>\mathrm{VP}>\mathrm{COW}>\mathrm{LABC}>\mathrm{GP}$. In addition, in the Hershberger assay for antiandrogenic activity, flutamide and $\mathrm{p}, \mathrm{p}^{\prime}$-DDE, reference antiandrogens, remarkably reduced the weights of sex accessory tissues, and in order of decreasing potency the effect was $\mathrm{SV}>\mathrm{VP}>\mathrm{COW}>\mathrm{LABC}>\mathrm{GP}$ by flutamide, and $\mathrm{SV}$ and $\mathrm{VP}>\mathrm{COW}>\mathrm{LABC}>\mathrm{GP}$ by $\mathrm{p}, \mathrm{p}^{\prime}$-DDE. These Hershberger assay results indicate that seminal vesicle tissue is most affected by both androgens and antiandrogens. In a similar fashion, the administration of permethrin to TPtreated castrated male rats by oral gavage for 10 days led to significant reductions in all of the androgen-dependent sex accessory tissue weights measured at all doses tested, and in order of decreasing potency the effect was $\mathrm{SV}>\mathrm{VP}>\mathrm{LABC}>\mathrm{COW}>\mathrm{GP}$. However, permethrin had no effect on the weights of sex accessory tissues when administered to castrated male rats without TP. These data indicate that permethrin has antiandrogenic activity, but it does not have androgenic activity. On the other hand, Kunimatsu et al. reported that permethrin has no androgenic and antiandrogenic effects in the Hershberger assay [25]. However, there are basic differences in assay protocols of the Hershberger assay used by Kunimatsu et al. [25] and the assay used in the present study. We performed the Hershberger assay according to the current draft guideline of the rodent Hershberger assay [35], while Kunimatsu et al. used the 5-day Hershberger assay (EDSTAC, 1998). In addition, Tyler et al. reported that permethrin exhibited approximately 500 -fold less antiandrogenic activity than flutamide in a human androgen receptor yeast screen assay [36]. Our results suggest that permethrin has estrogen-like effects on female rats, and antiandrogen-like effects on males, and therefore may affect the endocrine systems in rats.

\section{Acknowledgment}

We greatly appreciate the assistance of the National Institute of Toxicological Research, Korea Food and Drug Administration which provided a grant for this work. 


\section{References}

1. Safe SH. Endocrine disruptors and human health-is there a problem? An update. Environ Health Perspect 2000; 108: 487-493.

2. Colborn T, vom Saal FS, Soto AM. Developmental effects of endocrine-disrupting chemicals in wildlife and humans. Environ Health Perspect 1993; 101: 378384.

3. Tyler CR, Jobling S, Sumpter JP. Endocrine disruption in wildlife: a critical review of the evidence. Crit Rev Toxicol 1998; 28: 319-361.

4. Landrigan P, Garg A, Droller DB. Assessing the effects of endocrine disruptors in the National Children's Study. Environ Health Perspect 2003; 111: 1678-1682.

5. Narahashi T. Nerve membrane ionic channels as the target of toxicants. Arch Toxicol Suppl 1986; 9: 3-13.

6. Narahashi T, Carter DB, Frey J, Ginsburg K, Hamilton BJ, Nagata K, Roy ML, Song JH, Tatebayashi $\mathbf{H}$. Sodium channels and GABA receptor-channel complex as targets of environmental toxicants. Toxicol Lett 1995; 82-83: 239-245.

7. Bloomquist JR. Ion channels as targets for insecticides. Annu Rev Entomol 1996; 41: 163-190.

8. Schreck CE, Posey K, Smith D. Durability of permethrin as a potential clothing treatment to protect against blood-feeding arthropods. J Econ Entomol 1978; 71: 397-400.

9. Lines JD, Myamba J, Curtis CF. Experimental hut trials of permethrin-impregnated mosquito nets and eave curtains against malaria vectors in Tanzania. Med Vet Entomol 1987; 1: 37-51.

10. Sholdt LL, Schreck CE, Qureshi A, Mammino S, Aziz A, Iqbal M. Field bioassays of permethrintreated uniforms and a new extended duration repellent against mosquitoes in Pakistan. J Am Mosq Control Assoc 1988; 4: 233-236.

11. Lillie TH, Schreck CE, Rahe AJ. Effectiveness of personal protection against mosquitoes in Alaska. $J$ Med Entomol 1988; 25: 475-478.

12. Rashed S, Johnson $H$, Dongier $\mathbf{P}$, Moreau R, Lee $C$, Crepeau R, Lambert J, Jefremovas V, Schaffer C. Determinants of the permethrin impregnated bednets (PIB) in the republic of benin: the role of women in the acquisition and utilization of PIBs. Soc Sci Med 1999; 49: 993-1005.

13. Berger-Preiss E, Levsen K, Leng G, Idel H, Sugiri D, Ranft U. Indoor pyrethroid exposure in homes with woollen textile floor coverings. Int $\mathrm{J} \mathrm{Hyg}$ Environ Health 2002; 205: 459-472.

14. Cruz-Vazquez C, Altamira G, Ramos M, Medina L, Garcia-Vazquez Z, George J. Susceptibility of Haematobia irritans (Diptera: Muscidae) to permethrin in dairies in Aguascalientes, Mexico. $J$ Med Entomol 2002; 39: 939-941.
15. Zava DT, Blen M, Duwe G. Estrogenic activity of natural and synthetic estrogens in human breast cancer cells in culture. Environ Health Perspect 1997; 105 (Suppl 3): 637-645.

16. You L, Casanova M, Archibeque-Engle S, Sar M, Fan LQ, Heck HA. Impaired male sexual development in perinatal Sprague-Dawley and Long-Evans hooded rats exposed in utero and lactationally to p,p'-DDE. Toxicol Sci 1998; 45: 162173.

17. Sunami O, Kunimatsu T, Yamada T, Yabushita $S$, Sukata T, Miyata K, Kamita Y, Okuno Y, Seki T, Nakatsuka I, Matsuo M. Evaluation of a 5-day Hershberger assay using young mature male rats: methyltestosterone and p, $\mathrm{p}^{\prime}$-DDE, but not fenitrothion, exhibited androgenic or antiandrogenic activity in vivo. J Toxicol Sci 2000; 25 : 403-415.

18. Sohoni P, Lefevre PA, Ashby J, Sumpter JP. Possible androgenic/anti-androgenic activity of the insecticide fenitrothion. J Appl Toxicol 2001; 21: 173178.

19. Vinggaard AM, Nellemann C, Dalgaard M, Jorgensen EB, Andersen HR. Antiandrogenic effects in vitro and in vivo of the fungicide prochloraz. Toxicol Sci 2002; 69: 344-353.

20. Kitamura S, Suzuki T, Ohta S, Fujimoto N. Antiandrogenic activity and metabolism of the organophosphorus pesticide fenthion and related compounds. Environ Health Perspect 2003; 111: 503508.

21. Kang HG, Jeong SH, Cho JH, Kim DG, Park JM, Cho MH. Chlropyrifos-methyl shows antiandrogenic activity without estrogenic activity in rats. Toxicology 2004; 199: 219-230.

22. Okubo T, Yokoyama Y, Kano K, Soya Y, Kano I. Estimation of estrogenic and antiestrogenic activities of selected pesticides by MCF-7 cell proliferation assay. Arch Environ Contam Toxicol 2004; 46: 445-453.

23. Garey J, Wolff MS. Estrogenic and antiprogestagenic activities of pyrethroid insecticides. Biochem Biophys Res Commun 1998; 251: 855-859.

24. Saito K, Tomigahara $\mathrm{Y}$, Ohe N, Isobe N, Nakatsuka I, Kaneko H. Lack of significant estrogenic or antiestrogenic activity of pyrethroid insecticides in three in vitro assays based on classic estrogen receptor alpha-mediated mechanisms. Toxicol Sci 2000; 57: 54-60.

25. Kunimatsu T, Yamada T, Ose K, Sunami O, Kamita Y, Okuno Y, Seki T, Nakatsuka I. Lack of (anti-) androgenic or estrogenic effects of three pyrethroids (esfenvalerate, fenvalerate, and permethrin) in the Hershberger and uterotrophic 
assays. Regul Toxicol Pharmacol 2002; 35: 227-237.

26. Chen H, Xiao J, Hu G, Zhou J, Xiao H, Wang X. Estrogenicity of organophosphorus and pyrethroid pesticides. J Toxicol Environ Health A 2002; 65: 14191435.

27. Hong EJ, Choi KC, Jeung EB. Induction of calbindin-D9k messenger RNA and protein by maternal exposure to alkylphenols during late pregnancy in maternal and postnatal uteri of rats. Biol Reprod 2004; 71: 669-675.

28. An BS, Choi KC, Kang SK, Hwang WS, Jeung EB. Novel calbindin- $\mathrm{D}_{9 \mathrm{k}}$ protein as a useful biomarker for environmental estrogenic compounds in the uterus of immature rats. Reprod Toxicol 2003; 17: 311319.

29. An BS, Kang SK, Shin JH, Jeung EB. Stimulation of calbindin- $\mathrm{D}_{9 \mathrm{k}}$ mRNA expression in the rat uterus by octyl-phenol, nonylphenol and bisphenol. Mol Cell Endocrinol 2002; 191: 177-186.

30. Choi KC, Jeung EB. The biomarker and endocrine disruptors in mammals. J Reprod Dev 2003; 49: 337345.

31. Andrade AJ, Araujo S, Santana GM, Ohi M, Dalsenter PR. Screening for in vivo (anti)estrogenic and (anti)androgenic activities of technical and formulated deltamethrin. Regul Toxicol Pharmacol 2002; 35: 379-382.

32. Yamada T, Ueda S, Yoshioka K, Kawamura S, Seki T, Okuno Y, Mikami N. Lack of estrogenic or (anti-) androgenic effects of d-phenothrin in the uterotrophic and Hershberger assays. Toxicology 2003; 186: 227-239.

33. Go V, Garey J, Wolff MS, Pogo BG. Estrogenic potential of certain pyrethroid compounds in the MCF-7 human breast carcinoma cell line. Environ Health Perspect 1999; 107: 173-177.

34. Gierthy JF, Lincoln DW, Roth KE, Bowser SS, Bennett JA, Bradley L, Dickerman HW. Estrogenstimulation of postconfluent cell accumulation and foci formation of human MCF-7 breast cancer cells. $J$ Cell Biochem 1991; 45: 177-187.

35. Organization for Economic Cooperation and Development (OECD). Third meeting of the validation management group for the screening and testing of endocrine disruptors (mammalian effects). Joint meeting of the chemicals committee and the working party on chemicals, pesticide and biotechnology. 2001.

36. Tyler CR, Beresford N, Woning M, Sumpter JP, Thorpe K. Metabolism and environmental degradation of pyrethroid insecticiedes produce compounds with endocrine activities. Environ Toxicol Chem 2000; 19: 801-809.

37. Zou E, Hatakeyama M, Matsumura F. Foci formation of MCF-7 cells as an in vitro screening method for estrogenic chemicals. Environ Toxicol Chem 2002; 11: 71-77. 